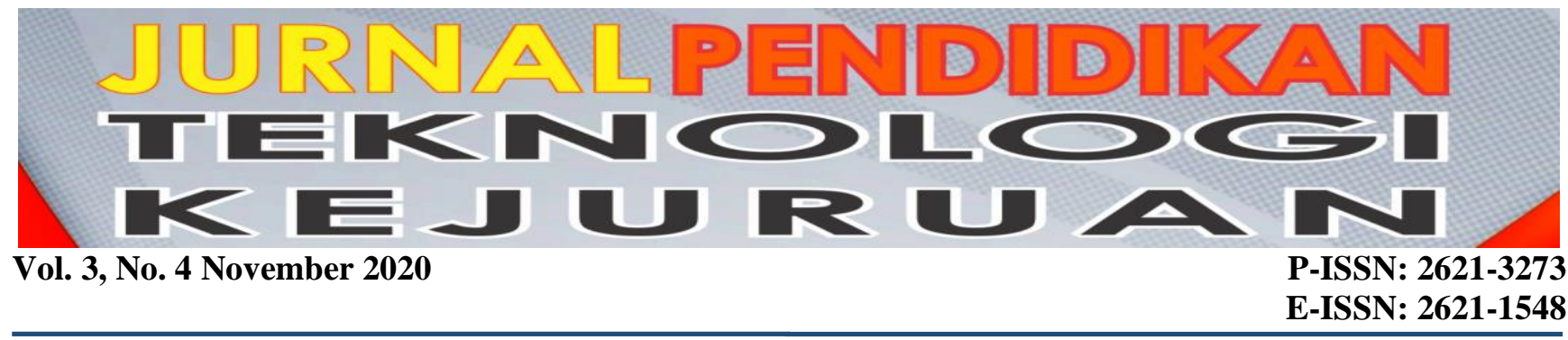

\title{
A Need Analysis for Development of Online Advertising E-Booklet on Entrepreneurship Education
}

\author{
Desy Wahyuningrum Mujiati ${ }^{1}$, Suyitno Muslim², Rina Febriana ${ }^{3}$ \\ ${ }^{1}$ Postgraduate of the Technology and Vocational Education, Universitas Negeri Jakarta \\ ${ }^{2,3}$ Technology and Vocational Education, Universitas Negeri Jakarta, Jakarta \\ "Corresponding author, e-mail: d.mujiati@gmail.com ${ }^{1}$
}

\begin{abstract}
This research aims to describe the results of the needs analysis for the development of online marketing e-booklet learning media in entrepreneurship subjects. In this research, the needs analysis refers to: (1) The great opportunity to become an entrepreneur in the Food \& Beverage (F\&B) Study Program because of the presence of online sales application technologies such as Gofood, Grabfood, and the Open PO sales system; (2) The problem of theoretical learning entrepreneurship; (3) Media needed in online marketing practices. This research uses survey, observation, interview and literature study methods in collecting data. The results of a survey conducted on alumni of SMK Tata Boga, namely $96 \%$ stated that attractive product images could attract consumers; $94 \%$ agree that making attractive drawings is part of entrepreneurship lessons. The results of the book literature study used marketing material is theoretical. The results of observations on students of class XI Observation and interviewing entrepreneurship teachers at SMK 1 Tambun Selatan found that: 1) Teachers still teach Offline marketing methods; 2) There is no interactive learning media to make online advertising on product marketing in entrepreneurship subjects. The results of this study concluded that students need interactive learning media in learning activities. Thus, this research is used in developing online advertising marketing e-booklet media on entrepreneurial subjects
\end{abstract}

Keywords: Needs Analysis, Media Development, Advertising, Marketing, Entrepreneurship

\section{INTRODUCTION}

In the era of pandemic covid-19, food selling through online is major thing. Many people afraid to go outside of their home so this opportunity must be defiantly for Food and Beverage Study Program became a study program that has advantages for entrepreneurship due to the technology of helping sell food and beverages online through Gofood and Grabfood as well as through sales on social media that are very easily adopted by consumers (Rahayu \& Sukardi, 2020). The online sales system at Gofood and Grabfood helps entrepreneurs to start a business from home, so that capital for rental building which expensive can be eliminated. Another advantage is that entrepreneurs can start a business with capital from their buyers through the Open PO (Open Purchase Order) sales system, which is usually done through social media information such as Facebook, Whatsapp and Instagram. Open PO is a food or beverage sales system where the seller informs in advance through a social media account that on a certain date the food seller will sell certain types of food and will be sent on the date specified by the seller, of course, interested consumers will transfer money in advance to the seller, so that the problem of venture capital can be solved because the seller has already obtained capital from the buyer.

The above type of sales is called the Online marketing, which is an online sale where purchases are made via mobile devices (online) but shipping uses offline services (Zhang, Pauwels, \& Peng, 2019) which have many advantages when compared to marketing Offline in general (banners, signposts, brochures), such as: (1) The coverage area on online is $5 \mathrm{~km}$, while offline is smaller that is $3 \mathrm{~km}$; (2) Service efficiency at online is higher while offline is lower; (3) Marketing ways on online faster while on offline is longer; (4) Marketing costs on online are cheaper while offline is more expensive. 
Although online sales technology can help product sales, but there are obstacles faced by entrepreneurs who are just starting the business, the stage of marketing process an introducing products to consumers which is closely related to promotion through advertising. An advertisement is usually related to an interesting visual of both words and images (Yaumi, 2018). Thinking about product marketing must be broadened because we have to find the right market segmentation and will be obtained when advertising is widespread. Of course the cost of advertising becomes a budget that must be taken into account so that advertising on online media can be an option because it is cheap, does not need to be printed. Attractive advertising design will increase the desire of consumers to buy products (Alalwan, 2018). This makes the problem in the marketing mix narrow and more tangible, how to make attractive online advertisements?.

The key to online advertising is the power of a product image that is visually appealing and able to arouse the desire to buy a product (Shaouf, $\mathrm{Lü}, \& \mathrm{Li}$, 2016) and is further strengthened by a survey conducted by Gofood that $80 \%$ of buyers are influenced by the appearance of photos on the storefront. Based on the information received from Gofood as shown on below image:

Picture 1. Percentage Influence of Product Photos Shown at Online Selling

GoFood

GO-FOOD -
Apa saja Syarat dan Ketentuan
untuk mengubah foto menu
menggunakan GoBiz?
Tahukah Anda, bahwa $80 \%$
pembelanjaan GoFood dipengaruhi
oleh tampilan foto menu pada
halaman aplikasi Anda. Karena itu,
pastikan bahwa Anda memasang foto
untuk semua menu Anda yang

Source: Gofood Merchant

While the Grabfood survey states that attractive images will increase sales by $30 \%$, so it is recommended to merchant partners who sell at Grabfood to display products with attractive images with several criteria that must be met such as: (1) Lighting in bright and clear photographs; (2) Photo quality is not blurred or broken; (3) There are no shadows that block food details; (4) One photo focus to display one type of food; (5) $500 \times 500 \mathrm{px}$ menu photo size; (6) Angle of food photos is clear and attractive as proven by below image:
Picture 2. Criteria of Product Photos at Online Selling

Source : Grabfood Merchant

GrobFood pusar merchar

Tips Meningkatkan Penjualan dari Foto Produk 1

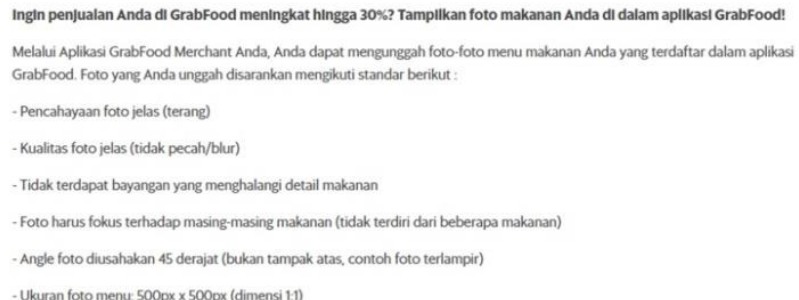

Nowadays, the F\&B industry demands on digital content marketing that are able to display the advantages of products that are visually picture and words appealing, require a students to upgrade their marketing skills (Bu, Parkinson, \& Thaichon, 2020). Entrepreneurship education is developing rapidly and demands improvement of teaching according to market needs (Ratten \& Usmanij, 2020).

The above data conclusions can be drawn on entrepreneurship lessons, it is important to learn how to make interesting product photos to make product sales could increased. Based on Laing's article (Laing \& Masoodian, 2016) making an attractive visual image of a product will use personal courage to explore the creativity of each individual but a guide is needed by students to reduced confusing in making interesting visuals. In education this will help students to understand online product marketing lessons by way of practice (Kriz, Nailer, Jansen, \& Potocnjak-Oxman, 2020). An image change and replacement by means of image combining and retouching processes according to Carlo Tuazon Sardez is called digital imaging (Reihan, 2010). Combining can also be interpreted by combining images with other images, effects or interesting words. Merging images, words that invite buyers and adding effects to images so that the message generated to consumers more clearly to buy products that are sold, will be further facilitated with the help of Photoshop software that is still popularly used in the design field. An entrepreneur must improve the ability of Practical knowledge that has the ability to be practical including product design (Espigares-jurado et al., 2020). This ability is important because the price of making product advertisements is relatively expensive, while advertising must be done often and consistently so that consumers continue to remember the products being sold. For beginner entrepreneurs who have limited capital, they must learn advertising design which assisted with Photoshop software in 
order to save expenses and be able to market their products to wider potential consumen

From the above background it can be concluded that displaying interesting product photos can increase sales, so the research continues by finding information on whether the SMK of food and beverage has taught this to students? If not, then it is necessary to develop a media that can help students learn digital imaging material more easily. This research of development media will be conduct on marketing material as part of entrepreneurship subjects at SMKN 1 Tambun Selatan.

\section{METHODOLOGY}

This research was the first stage of research and development (R\&D) instructional methods (Arthur, Riyan; Luthfiana, Yusrina; Musalamah, 2019), was limited to analyzing needs by making observations. The research involved 47 alumni who participated in giving opinions about the marketing material they had learned from school whether it affected their interest in entrepreneurship.

Entrepreneurial skill very important after they graduate from school because they already learned all material of entrepreneurship at school thats why the information was collected from alumni because entreprenurship in vocational education is dedicated to a person who already pass education at SMK so they can clearly submit the information needed by researcher.

The data are obtained from several source and processed in five stages:

Table 1. Stage of Data's Collecting

\begin{tabular}{llc}
\hline No & \multicolumn{1}{c}{ Stages } & Amount \\
\hline A. & $\begin{array}{l}\text { Survey alumni } \\
\text { B. }\end{array}$ & $\begin{array}{l}\text { Literature study of } \\
\text { Entrepreneurship book } \\
\text { for SMK/MAK } \\
\text { curriculum 2013- }\end{array}$ \\
& $\begin{array}{l}\text { revision edition } \\
\text { C. }\end{array}$ & $\begin{array}{l}\text { Student's Interview } \\
\text { D. }\end{array}$ \\
& $\begin{array}{l}\text { Observation of teaching } \\
\text { methods carried out by } \\
\text { teachers }\end{array}$ & 10 persons \\
E. & $\begin{array}{l}\text { Making Interpretations of } \\
\text { the problem analysis to } \\
\text { make a conclusion }\end{array}$ & final \\
&
\end{tabular}

A. Survey Alumni

An alumni survey was conducted with a Google form with the help of a teacher who spread information about this questionnaire in the watsapp alumni group, this research to find out thoroughly whether lessons given at school affect entrepreneurial abilities.

B. Literarure study by studying the material given by teachers from books used at school.

C. Student's Interview

to find out whether the material provided is in accordance with current market needs.

D. Observation of teaching methods carried out by teachers

to find out theteaching methods and material have a narrow gab with current market needs.

E. Making Interpretations of the problem analysis to make a conclusion which media should be developed to achieve quality education which potentially create a new entrepreneurship in future.

\section{RESULTS AND DISCUSSION}

This phase of analysis need was done to connect the needs of industry in the real world with the pattern of education which was carried out, so education can find the problem and try to develop a new media to solve the problem.

\section{A. Survey Alumni}

Table 2. Result Alumni's Survey

\begin{tabular}{|c|c|}
\hline No & Survey Analysis \\
\hline 1. & $47 \%$ are jobless. \\
\hline 2. & $\begin{array}{l}32 \% \text { answered that they are dissatisfied with } \\
\text { the way of teacher's taught. }\end{array}$ \\
\hline 3. & $98 \%$ answered interested in entrepreneurship \\
\hline 4. & $\begin{array}{l}19 \% \text { answered they didn't have a capital to } \\
\text { start an entrepreneurship. }\end{array}$ \\
\hline 5. & $\begin{array}{l}96 \% \text { answered attractive advertisement will } \\
\text { influence to buy a product. }\end{array}$ \\
\hline 6. & $\begin{array}{l}94 \% \text { answered attractive advertisement } \\
\text { should be teach at entrepreneurship } \\
\text { education. }\end{array}$ \\
\hline
\end{tabular}

B. Literature Study

The book used at SMK grade XI teached marketing theoretically in the form of definitions, whereas in the real world the problem of marketing cannot be solved by definition but must be practice.

\section{Student's Interview}

The student's answered they learned marketing product theoritical by book and the teacher let them learned marketing by selling the food they have made and peddling around the school and and that is time 
consuming and number of sales are very low because the area covered is very limited.

\section{Observation of Teaching Method}

Interview results teacher said they found some difficulties in teaching product marketing because the book used only tought marketing definitions and concepts without having a practical load. The book only asks for an actual discussion due to the students has not experienced yet so the students felt confusion. Furthermore to help marketing education, the teacher used a kitchen laboratory for practice making food and sold by peddling the dishes around the school. Educators at SMKN 1 Tambun Selatan mention there are no media that help teachers in teaching online marketing so in this study conducted to develop learning media that will help students practice online marketing materials that are relevant to the real world and able to help students market their products online.

\section{E. Analysis Intrepretation}

We can found an interesting facts that $98 \%$ expressed interest in entrepreneurship but $47 \%$ of alumni are unemployed and did not have a dare to try entrepreneurship because 19\% stated they did not have capital eventough it can be solved by Open PO sales system, capital problems can be overcome because capital is obtained from buyers as explained in the introduction (first paragraph). Continuing survey result 96\% mentioned advertisement will influence to buy a product this statement is also evidenced by the many articles that are disclosed that interesting articles stated that images will influence the desire to purchase intention (Bambauer-Sachse \& Heinzle, 2018; Kytö, Virtanen, \& Mustonen, 2019; McClure \& Seock, 2020). Last survey said that $94 \%$ stated that entrepreneurship lessons should teach to make attractive advertisements, because it is mentioned above that attractive advertisements have the potential to increase product sales which will affect the existence of business development. But in reality the study of literature the book used still teaches theorytical and concepts instead of teaching a practice. According to Charles Allen Prosser (Anwar, 2009) in the third principle that vocational education will be effective if it teaches acting according to the needs of its work, while the needs of an entrepreneur work must market their products.

From student's interview and observation teaching method, the outhor conclude that the teacher still teached offline marketing by peddling around to selling the food. This is ineffective and inefficient in time and effort, because the market share is limited only when the seller passed the consumen, even though the potential consumer is very broad. Based on the article of Zhang (Zhang et al., 2019) - (introduction paragraph 2) there are many benefits will gained from online marketing types, so due to schools already teach offline marketing, the writer will teach online marketing .

The next step is to choose the right media to teach this material. Media development is needed for increasing achievement of more active learning, according to Yaumi (Yaumi, 2018) the urgency of developing learning media is because (1) Improving the quality of learning; (2) demands of a new paradigm where students can learn independently; (3) Market needs so graduates are able to follow market developments; and (4) Vision of global education students can learn wherever and whenever.

Media according to the Association for Education and Communication Technology (AECT) is all matters relating to the process of channeling messages in the learning process (Satrianawati, 2018) Research conducted by Antoniu Abreu (Abreu, Rocha, Carvalho, \& Pérez Cota, 2017) who uses ebooklets in spreading information in the learning process inspires writers to create the same media, ebooklets. These considerations are based on (1) ebooklets are easily distributed to students because in covid-19 are there is no face-to-face meeting at school, so with this media distance learning is easy to distributed; (2) E-booklets are a combination of ebooks and leaflets that combine subject matter with interesting images, so hopefully students are more interested in colorful media and make them active learning.

\section{CONCLUSION}

The results of the discussion above are as follows: (1) $94 \%$ of alumni state that teaching visual draws that are interesting should be taught in entrepreneurship subjects and this is supported by several articles (2) The results of literature studies state that books still teach theory only (3) Interview results students and teaching observations that teachers still teach offline marketing. So this research will develop a media ebooklets which interesting media and colorful to teach online marketing theoritical and practices in the hope of creating active learning and increasing the chances of students becoming entrepreneurs in an easy and inexpensive way.

\section{REFERENCES}

Abreu, A., Rocha, Á., Carvalho, J. V. de, \& Pérez Cota, M. (2017). The electronic booklet on teaching-learning process: Teacher vision and parents of students in primary and secondary education. Telematics and Informatics, 34(6), 861-877. https://doi.org/10.1016/j.tele.2016.08.011 
Alalwan, A. A. (2018). International Journal of Information Management Investigating the impact of social media advertising features on customer purchase intention. International Journal of Information Management, 42(June), 65-77.

https://doi.org/10.1016/j.ijinfomgt.2018.06.001

Anwar, M. I. (2009). Implementasi Manajemen Stratejik Dalam Pemberdayaan Sekolah Menengah Kejuruan. Bandung: Citapustaka Media Perintis.

Arthur, Riyan ; Luthfiana, Yusrina; Musalamah, S. (2019). Analisa Kebutuhan Pengembangan Media Pembelajaran Pada. Jurnal Pendidikan Teknik Sipil (Jpensil), (December). https://doi.org/10.24114/ebjptbs.v5i2

Bambauer-Sachse, S., \& Heinzle, P. (2018). Comparative advertising: Effects of concreteness and claim substantiation through reactance and activation on purchase intentions. Journal of Business Research, 84(May 2017), 233-242. https://doi.org/10.1016/j.jbusres.2017.11.025

Bu, Y., Parkinson, J., \& Thaichon, P. (2020). Digital content marketing as a catalyst for e-WOM in food tourism, (xxxx), 1-12. https://doi.org/10.1016/j.ausmj.2020.01.001

Espigares-jurado, F., Muñoz-leiva, F., Correia, M. B., Sousa, C. M. R., Ramos, C. M. Q., \& Faísca, L. (2020). Journal of Retailing and Consumer Services Visual attention to the main image of a hotel website based on its position, type of navigation and belonging to Millennial generation: An eye tracking study. Journal of Retailing and Consumer Services, 52(August 2019), 101906. https://doi.org/10.1016/j.jretconser.2019.10190 6

Kriz, A., Nailer, C., Jansen, K., \& PotocnjakOxman, C. (2020). Teaching-practice as a critical bridge for narrowing the researchpractice gap. Industrial Marketing Management, (June 2019), 1-13. https://doi.org/10.1016/j.indmarman.2020.02.0 17

Kytö, E., Virtanen, M., \& Mustonen, S. (2019). From intention to action: Predicting purchase behavior with consumers' product expectations and perceptions, and their individual properties. Food Quality and Preference, 75(February), 1-9. https://doi.org/10.1016/j.foodqual.2019.02.002

Laing, S., \& Masoodian, M. (2016). A study of the influence of visual imagery on graphic design ideation. Design Studies, 1-23. https://doi.org/10.1016/j.destud.2016.04.002

McClure, C., \& Seock, Y. K. (2020). The role of involvement: Investigating the effect of brand's social media pages on consumer purchase intention. Journal of Retailing and Consumer Services, 53(October 2019), 101975. https://doi.org/10.1016/j.jretconser.2019.10197 5

Rahayu, I., \& Sukardi, S. (2020). a Needs Analysis for the Development of E-Modules ProjectBased Learning. Jurnal Pendidikan Teknologi Kejuruan, 3(1), 41-45. https://doi.org/10.24036/jptk.v3i1.3923

Ratten, V., \& Usmanij, P. (2020). The International Journal of Entrepreneurship education : Time for a change in research direction? The International Journal of Management Education, (November 2019), 100367. https://doi.org/10.1016/j.ijme.2020.100367

Reihan, F. (2010). New Concept of Digital imaging. Jakarta: PT Elex Media Computindo.

Satrianawati. (2018). Media dan Sumber Belajar. Sleman: CV Budi Utama.

Shaouf, A., Lü, K., \& Li, X. (2016). Computers in Human Behavior The effect of web advertising visual design on online purchase intention : An examination across gender. Computers in Human Behavior, 60, 622-634. https://doi.org/10.1016/j.chb.2016.02.090

Yaumi, M. (2018). Media dan Teknologi Pembelajaran. Jakarta: Prenadamedia Group.

Zhang, S., Pauwels, K., \& Peng, C. (2019). ScienceDirect The Impact of Adding Onlineto-Offl ine Service Platform Channels on Firms ' Offline and Total Sales and Profits. Journal of Interactive Marketing, 47, 115-128. https://doi.org/10.1016/j.intmar.2019.03.001 